\title{
Pasture characteristics and productive performance of dairy cows under two grazing management strategies
}

\author{
Características das pastagens e desempenho produtivo de vacas \\ leiteiras sob duas estratégias de manejo de pastejo
}

\author{
Alberto Magno Fernandes ${ }^{1}$; Tadeu Silva de Oliveira ${ }^{1 *}$; Alisson Rodrigues Jordão ${ }^{2}$; \\ Domingos Sávio Campos Paciullo ${ }^{3}$; Danielle Ferreira Baffa ${ }^{4}$; \\ Michele Gabriel Camilo ${ }^{4}$
}

\section{Highlights:}

Light interception of $95 \%$ by the canopy reduce defoliation intervals.

Protein increased in the pastures managed at the longer defoliation interval.

Performance increased in the pastures managed with the variable defoliation interval.

\begin{abstract}
The objective of this work was to evaluate the supply, morphological and chemical composition of forage, performance and milk composition of crossbred cows managed in Megathyrsus maximus cv. Tanzania in intermittent grazing system with fixed and variable defoliation intervals according to the interception of $95 \%$ of photosynthetically active radiation by the canopy. The experimental design was a randomized complete block design with two treatments and two area replications. In each grazing cycle the supply, morphological composition, forage nutritive value, dry matter intake, milk production and composition were determined. The experimental area was 4.0 hectares, divided into two blocks of 2 hectares. Each block was subdivided into 22 pickets ( 11 for each treatment) totaling 44 pickets with an area of $909 \mathrm{~m} 2$ each. Significant differences $(\mathrm{P}<0.05)$ were observed for leaf blade content, in vitro digestibility of dry matter and forage crude protein, dry matter intake, individual and area milk production and lactose content milk, being the highest values found in the pastures managed with variable defoliation interval. Thus, the defoliation interval defined by the $95 \%$ interception of the photosynthetically luminosity leads to higher leaf blade proportions in the forage canopy, resulting in higher individual milk yield and per unit area, but with a loss of protein and total solids contents of milk. Key words: Dairy cows. Grazing. Milk yield. Megathyrsus maximus.
\end{abstract}

\section{Resumo}

Objetivou-se com esse trabalho avaliar a oferta, composições morfológica e química da forragem, o desempenho animal e a composição do leite de vacas mestiças manejadas em pastagens de Megathyrsus

\footnotetext{
1 Profs. Drs., Universidade Estadual do Norte Fluminense, UENF, Laboratório de Zootecnia, Campos dos Goytacazes, RJ, Brasil. E-mail: alberto@uenf.br; tsoliveira@uenf.br

2 Prof. Dr., Instituto Federal do Maranhão, IFMA, São Luís, MA, Brasil. E-mail: alissonjordao@hotmail.com

3 Pesquisador, Dr., Empresa Brasileira de Pesquisa Agropecuária, EMBRAPA Gado de Leite, Juiz de Fora, MG, Brasil. E-mail: domingos.paciullo@embrapa.br

4 Discentes do Curso de Doutorado do Programa de Pós-Graduação em Ciência Animal, UENF, Campos dos Goytacazes, RJ, Brasil.E-mail: danibaffa@gmail.com; michelegabrielc@hotmail.com

* Author for correspondence
} 
maximus cv. Tanzania em sistema intermitente de pastejo com intervalos de desfolhação fixos e variáveis de acordo com a interceptação de $95 \%$ da radiação fotossinteticamente ativa pelo dossel. O delineamento experimental utilizado foi de blocos ao acaso, com dois tratamentos e duas repetições de área, em cada ciclo de pastejo foi determinado a oferta, composição morfológica, valor nutritivo da forragem, consumo de matéria seca, produção e a composição do leite. A área experimental foi de 4,0 hectare, dividida em dois blocos de 2 hectare cada. Cada bloco foi subdividido em 22 piquetes (11 para cada tratamento) totalizando 44 piquetes com uma área de $909 \mathrm{~m}^{2}$ cada. Foram observadas diferenças significativas $(\mathrm{P}<0,05)$ para a proporção de lâminas foliares, digestibilidade in vitro da matéria seca e proteína bruta da forragem, no consumo de matéria seca, na produção de leite individual e por área e no teor de lactose do leite, sendo os maiores valores encontrados nos pastos manejados com intervalo de desfolha variável. Sendo assim, o intervalo de desfolha definido pela interceptação de $95 \%$ da luminosidade fotossinteticamente ativa leva a maiores proporções de lâmina foliar no dossel forrageiro, resulta em maior produção de leite individual e por unidade de área, porém com prejuízo aos teores de proteína e sólidos totais do leite.

Palavras-chave: Megathyrsus maximus. Pastejo. Produção de leite. Vacas leiteiras.

\section{Introduction}

The low productivity of pasture areas in Brazil is the main cause of the low profitability and competitiveness of livestock systems compared with other agricultural activities. In this scenario, the adoption of management practices that increase pasture use efficiency can help address this problem by maintaining the pasture in structural conditions that maximize production efficiency and the harvest of herbage (Reis, Ruggieri, Oliveira, Azenha, \& Casagrande, 2012). Considering that the canopy structure influences the herbage intake and performance of animals, management strategies should be established according to pasture conditions, with targets defined in terms of canopy height or herbage mass (Euclides, Montagner, Difante, Barbosa, \& Fernandes, 2014).

In an intermittent grazing system, the defoliation interval is the variable that determines the recovery of the leaf area index and, consequently, herbage production. The defoliation interval is usually defined based on chronological criteria such as number of days. However, because plant growth rates vary across seasons, this is not the best criterion use.

Nevertheless, management proposals that take into account the phenology and physiology of each cultivar may lead to improvements in pasture productivity and perenniality rates. As a consequence, herbage intake and harvesting efficiency can increase, leading to higher milk yields per animal and per area using the same amount of feedstock (Shallo, Creighton, \& O'Donovan, 2011). For the management of grazing, a criterion based on the interruption of the regrowth period when plants intercept $95 \%$ of the incident light has been proposed. At that point, the critical leaf area index and maximum herbage accumulation rate are attained (Sousa et al., 2011; Zanine et al., 2011). For tropical forages, there have been reports of increased leaf senescence and stem growth rates after the forage canopy reached $95 \%$ of interception of the incident light (Zanine et al., 2011).

The aim of the present study was thus to evaluate pasture characteristics and productive performance of dairy cows reared on Tanzania grass (Megathyrsus maximus cv. Tanzania) pastures in an intermittent grazing system with fixed and variable defoliation intervals according to the interception of $95 \%$ of the photosynthetically active radiation by the canopy.

\section{Material and Methods}

The experiment was conducted on the José Henrique Bruschi Experimental Field of EMBRAPA Dairy Cattle, located in Coronel Pacheco-MG,

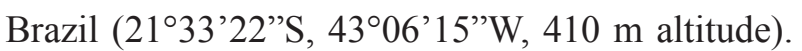


The total experimental period was 162 days. According to the Köppen classification, the climate of the region is a Cwa type (mesothermal), defined as rainy temperate in the summer with dry winters.

The relief in the experimental area can be considered undulating; the soil is classified as a colluvial fluvial $\mathrm{Tb}$ typical dystrophic type with a moderate A horizon and medium clayey texture; and the vegetation is a tropical evergreen forest. Chemical analysis was performed on the $0-20 \mathrm{~cm}$ of soil, and based on the results, the paddocks received maintenance fertilization using NPK (20-05-20). The total amount of fertilizer applied corresponded to $150 \mathrm{Kg} / \mathrm{ha} \mathrm{N}, 37.5 \mathrm{Kg} / \mathrm{ha} \mathrm{P}_{2} \mathrm{O}_{5}$, and $150 \mathrm{Kg} / \mathrm{ha}$ $\mathrm{K}_{2} \mathrm{O}$, which was split into three applications, soon after the animals left each paddock.

A randomized-block design with two treatments and two area replicates was implemented. The experimental area consisted of 4.0 ha, which was divided into two 2-ha blocks. Each block was subdivided into 22 paddocks (11 for each treatment) totaling 44 paddocks each measuring $909-\mathrm{m}^{2}$.

Treatments consisted of two management strategies: one was defined by the entrance of the animals in the paddocks when the canopy intercepted $95 \%$ of the photosynthetically active radiation (PAR); and the other was a fixed 30-day defoliation interval. In both treatments, the occupation period was three days, and a post-grazing residual height of $40 \mathrm{~cm}$ was the target. Prior to the start of the evaluations, however, the animals were allowed a period to acclimate to the research conditions, which also allowedfor the formation of the grazing gradient. During this period, the paddocks were managed with the defoliation intervals defined for each treatment, resulting in the conclusion of one grazing cycle before the beginning of sample collection.

The interception of the PAR by the canopy was monitored before the animals entered a paddock, in both treatments. For the assessment, a canopy analyzer [AccuPAR Linear PAR/LAI ceptometer,
Model PAR-80 (DECAGON Devices)] was used to collect the data, with readings taken from 20 points in each paddock. The points were the readings were taken were defined previously by walking in a zigzag pattern path along the entire sampled paddocks, at every grazing cycle.

The herbage mass was estimated by harvesting samples at the soil level, using a metal frame $(0.5$ $\mathrm{m}^{2}$ ), at three points representatives of the average canopy height, which were defined at random in each of the six sampled paddocks from each treatment, at each grazing cycle. The average canopy height was determined using a graduated ruler at 30 random points per paddock, where each point corresponded to the height from the soil level to the curvature of the last fully expanded leaf around the ruler. Two 400-g composite sub-samples were taken from the material collected from each paddock. One was used to determine dry matter in air, while the other was separated into the leaf blade, stem (stem + sheath), and senescent material (leaves or stem with a dry area of over $50 \%$ ) fractions to determine the morphological composition of the herbage. All samples were weighed and then dried in a forced-air oven at $\pm 55^{\circ} \mathrm{C}$ until reaching a constant weight.

At every grazing cycle, before the animals entered the paddock, the consumed herbage was harvested to analyze its chemical composition and in vitro dry matter digestibility (IVDMD). For this step, the hand-pluck (grazing simulation) method was performed by collecting the herbage manually with a cleaver at fifteen points representatives of each of the six sampled paddocks. To define the harvesting height, we observed the behavior of the animals and the residual heights of the newly grazed adjacent paddocks. A 400-g sub-sample was taken from the material collected in each paddock and dried in a forced-air oven at $\pm 55^{\circ} \mathrm{C}$ until reaching a constant weight. Afterwards, it was ground through a Wiley mill with a 1-mm sieve.

The concentrations of dry matter (DM), ether extract (EE), ash, crude protein (CP), acid detergent 
insoluble nitrogen (ADIN), neutral detergent insoluble nitrogen (NDIN), neutral detergent fiber (NDF), acid detergent fiber (ADF), and lignin were determined as proposed by the Association of Official Analytical Chemistry [AOAC] (1990). The in vitro dry matter digestibility, in turn, was determined by following the methodologies described by Silva and Queiroz (2006).

The intermittent grazing method with variable stocking rate was adopted. Twenty lactating crossbred (Holstein $\times$ Zebu) cows were used as test animals, at the rate of 10 animals per treatment. Aiming at greater homogeneity, the animals were distributed into the treatments according to milk yield, number of lactations, live weight, and genetic group. The stocking rate was adjusted according to the management target by the 'put-and-take' technique, according to which lactating cows with similar characteristics to those used in the experimental group were used whenever necessary as regulator (put-and-take) animals.

Cows were supplemented individually with 2 $\mathrm{kg}$ of balanced concentrate per day, which were split into two equal daily supplies, during milking. A mineral-vitamin supplement was provided ad libitum throughout the waiting period before and after milking, when the animals would also have access to water. The chemical analysis of samples of supplement harvested during the experimental period revealed the following average composition: $\mathrm{DM}=935.0 \mathrm{~g} / \mathrm{kg} ; \mathrm{CP}=201.0 \mathrm{~g} / \mathrm{kg} \mathrm{DM} ; \mathrm{NDF}=$ $191.0 \mathrm{~g} / \mathrm{kg} \mathrm{DM} ; \mathrm{ADF}=84.0 \mathrm{~g} / \mathrm{kg} \mathrm{DM} ;$ lignin $=17.0$ $\mathrm{g} / \mathrm{kg} \mathrm{DM}$; ether extract $=22.0 \mathrm{~g} / \mathrm{kg} \mathrm{DM}, \mathrm{ash}=83.0$ $\mathrm{g} / \mathrm{kg} \mathrm{DM}$; and IVDMD $=868.0 \mathrm{~g} / \mathrm{kg}$ DM.

The individual milk yield of the cows was recorded daily during the entire experimental period. Cows were milked at $0600 \mathrm{~h}$ and $1500 \mathrm{~h}$. To determine the chemical composition of milk, it was collected at every 14 days, for three consecutive days, in bottles with capacity of approximately $60 \mathrm{~mL}$ containing the preservative 2-bromo-2nitropropane-1-3-diol. Samples were analyzed at the Laboratory of Milk Quality of EMBRAPA Dairy Cattle, by the mid-infrared absorption method.

Milk yield was corrected for 3.5\% fat (FCMY) using the following equation proposed by Gaines (1928): FCMY $=\{[0.4225 \times$ milk yield $(\mathrm{kg})]+$ $[16.216 \times(\%$ fat $/ 100) \times$ milk yield $(\mathrm{kg})]\}$. Milk yield per area ( $\mathrm{kg}$ of milk/ha) was corrected for all grazing cycles, due to the variation in the area used in the treatments according to the management strategy used. Feed efficiency was calculated for each cow by dividing the average milk yield by the average DM intake during the experimental period.

The individual DM intake from the herbage was estimated at every grazing cycle based on the fecal production and IVDMD values, using the equation below:

Daily DM intake $(\mathrm{kg})=[$ Daily fecal excretion $(\mathrm{kg}) \times 100] / \mathrm{DM}$ indigestibility $(\%)$,

where DM indigestibility $=100$ - IVDMD. The daily fecal excretion was estimated using chromium oxide $\left(\mathrm{Cr}_{2} \mathrm{O}_{3}\right)$ as an external marker, which was administered to the animals twice daily, in 5-g doses. Fecal excretion was calculated by the following equation:

Daily fecal excretion $(\mathrm{kg})=$ Supplied chromium (g/day)/Chromium concentration in the feces

To analyse the concentration of chromium present in the feces, the collected samples were dried in a forced-air oven at $55 \pm 55^{\circ} \mathrm{C}$ until reaching a constant weight and subsequently ground using a 1-mm mill. Faecal samples were subjected to nitricperchloric acid wet digestion as described by Kimura and Miller (1957). Next, they were analyzed for the concentrations of chromium by atomic absorption spectrophotometry.

The parameters were estimated using the mixedmodels procedure for repeated measures (PROC MIXED) of SAS statistical software (SAS Institute, Inc., Cary, NC, USA), considering the block as a random effect and cycle and management methods as fixed effects. The model with the best quality of 
fit was determined by Akaike's information criteria (Akaike, 1974). Means were compared by Tukey's test at a confidence level of $95 \%$.

\section{Results and Discussion}

According to the variables associated with the productive characteristics of the pasture (Table 1), the use of a variable defoliation interval based on the interception of $95 \%$ of the photosynthetically active ration (PAR) by the canopy as the criterion for defining the moment to interrupt regrowth resulted in shorter defoliation intervals $(\mathrm{P}<0.001)$ and a consequent increase in the number of grazing cycles during the experimental period. This is closely related to the erect growth habit of this species, whose vertical architecture, despite increasing its height, will always enable the passage of radiation towards regions below the canopy (Macedo et al., 2017).

Table 1

Mean values for the interception of the photosynthetically active radiation (PAR) by the canopy; defoliation interval; herbage allowance; concentrations of leaf blade, stem, dead herbage, dry matter, neutral detergent fiber, acid detergent fiber, ether extract, lignin, ash, and crude protein; and in vitro dry matter digestibility (IVDMD) of Megathyrsus maximus cv. Tanzania pastures subjected to a variable (TZ95) or a fixed 30-day (TZ30) defoliation interval

\begin{tabular}{lcccc}
\hline \multirow{2}{*}{ Component } & \multicolumn{2}{c}{ Management strategy } & \multirow{2}{*}{ SEM $^{(1)}$} & P-value \\
\cline { 2 - 3 } & TZ95 & TZ30 & & $<.32$ \\
PAR interception (\%) & 94.92 & 98.20 & & $<0001$ \\
Defoliation interval (days) & 22.8 & 30 & 1.64 & $<0.0001$ \\
Herbage allowance (\% live weight) & 4.46 & 5.53 & 0.29 & 0.002 \\
Leaf blade (g/kg DM) & 446.14 & 394.42 & 18.45 & 0.04 \\
Stem (g/kg DM) & 336.19 & 393.44 & 26.82 & 0.06 \\
Dead herbage (g/kg DM) & 104.88 & 106.65 & 1.71 & 0.53 \\
& & Chemical composition & \\
Dry matter (g/kg DM) & 201.79 & 201.17 & 6.54 & 0.93 \\
Neutral detergent fiber (g/kg DM) & 693.39 & 692.64 & 4.33 & 0.91 \\
Acid detergent fiber (g/kg DM) & 365.63 & 370.53 & 4.45 & 0.44 \\
Ether extract (g/kg DM) & 19.00 & 17.74 & 0.83 & 0.24 \\
Lignin (g/kg DM) & 33.34 & 35.88 & 1.21 & 0.11 \\
Ash (g/kg DM) & 104.88 & 106.65 & 1.71 & 0.47 \\
Crude protein (g/kg DM) & 141.27 & 119.91 & 4.80 & $<0.0001$ \\
IVDMD (g/Kg DM) & 588.66 & 563.37 & 6.79 & 0.01 \\
\hline
\end{tabular}

${ }^{(1)}$ Standard error of the mean. ${ }^{(2)}$ Probability.

In this way, the strategy of allowing entrance into the paddock when it reached $95 \%$ interception of the PAR resulted in an average grazing interval of 22.8 days (Table 1$)$, which is less $(\mathrm{P}<0.0001)$ than the fixed interval of 30 days. The productive potential of the grass coupled with the applied fertilization and adequate soil-climatic conditions for its growth can explain the obtained results. Furthermore, despite the observed lower herbage allowance $(4.46 \%$ in relation to the fixed interval, which was $5.53 \%$ of the live weight), the adoption of a variable defoliation interval resulted in pastures with larger $(\mathrm{P}=0.04)$ proportions of leaf blade (Table 1). Although stem elongation is favorable to 
elevate DM production, it may negatively influence grazing efficiency and the nutritional value of the produced herbage, in addition to extending the leaf appearance interval; i.e., the phyllochron (Macedo et al., 2017).

The management based on the interception of $95 \%$ of the PAR was more favorable to the grazing activity, considering the cattle's priority to select leaves, which have the highest nutritional value, over stems (Euclides et al., 2009). Pinheiro et al. (2015) further stressed the positive relationship between the proportion of leaves in the pasture and herbage intake, which benefits the performance of cattle in a grazing regime.

Despite showing little evidence of effects $(0.05$ $<$-value $<0.10)(\mathrm{P}=0.06)$, the proportion of stem was similar to the proportion of senescent material $(\mathrm{P}=0.53)$ across the management strategies (Table 1). The observed results are similar to those obtained by Silva et al. (2009), who did not find differences in the proportion of senescent material and stems in pastures of mombasa guinea grass managed with defoliation intervals determined by the interception of $95 \%$ or $100 \%$ of the PAR by the canopy.

By analyzing the chemical composition of the herbages, we observe that the DM ( $\mathrm{P}=0.93)$, NDF $(\mathrm{P}=0.91)$, ADF $(\mathrm{P}=0.44)$, EE $(\mathrm{P}=0.24)$, lignin $(\mathrm{P}=0.11)$, and ash $(\mathrm{P}=0.47)$ contents were not affected by the adopted management strategy (Table
1). The literature constantly describes increases in NDF content as the growth period is prolonged or as the grazing days pass. However, in the current experiment, the period of seven days $[$ TZ95 $=22.8$ and $\mathrm{TZ30}=30$ (Table 1)] was not sufficient for this occurrence to be observed.

However, the concentrations of $\mathrm{CP}(\mathrm{P}<0.0001)$, NDIN ( $\mathrm{P}=0.0008)$, ADIN ( $\mathrm{P}=0.01)$, and IVDMD $(\mathrm{P}=0.01)$ were higher in the pastures managed at the longer defoliation interval (Table 1).

The higher $\mathrm{CP}$ content observed in those pastures may be attributed to the greater participation of green and tender leaf blades in the forage canopy, due to the younger age of the plants (22.8 days) when compared with that of the plants managed at 30 days of defoliation. It is notable that diets with $\mathrm{CP}$ levels lower than $70 \mathrm{~g} / \mathrm{kg}$ can cause an imbalance in rumen degradation and microbial synthesis (Van Soest, 1994; Gomes et al., 2016). In our study, as can be observed, CP values ranged between 141.27 (TZ95) and 119.91 (TZ30) g/kg DM (Table 1). It should be stressed that pastures managed with 95\% interception of the PAR will also provide larger quantities of fermentable carbohydrates, potentiating microbial synthesis (Andrade-Montemayor, Gasca, $\&$ Kawas, 2009). This results in a shorter retention time of the herbage in the rumen (Gomes et al., 2016), ultimately maximizing intake (Table 2) and animal performance (Table 3 ).

\section{Table 2}

Dry matter intake and feed efficiency (FE) of lactating cows reared on Megathyrsus maximus cv. Tanzania subjected to a variable (TZ95) or a fixed 30-day (TZ30) defoliation interval

\begin{tabular}{|c|c|c|c|c|}
\hline \multirow{2}{*}{ Component } & \multicolumn{2}{|c|}{ Management strategy } & \multirow{2}{*}{$\mathrm{SEM}^{(1)}$} & \multirow{2}{*}{$P$-value ${ }^{2}$} \\
\hline & TZ95 & TZ30 & & \\
\hline Total dry matter intake (kg DM/day) & 16.24 & 15.00 & 0.46 & 0.03 \\
\hline Herbage intake (kg DM/day) & 14.53 & 13.29 & 0.46 & 0.01 \\
\hline FE (L of milk/kg DM intake) & 1.90 & 1.48 & 0.09 & $<0.0001$ \\
\hline
\end{tabular}

${ }^{(1)}$ Standard error of the mean. ${ }^{(2)}$ Probability. 
However, Valente et al. (2010) evaluated Tanzania grass pastures managed at 85,95 , and $97 \%$ light interception by the forage canopy and observed CP values of $12.1,11.6$, and $11.5 \%$, for the respective treatments, which are lower than those obtained in the current study. This difference reveals the existing variability in the $\mathrm{CP}$ content of tropical grasses found in the literature, as this component is influenced by several factors such as plant age, fertilization, season of the year, and defoliation interval.

\section{Table 3}

Mean values for milk yield, 3.5\% fat-corrected milk yield (FCMY), and concentrations of protein, lactose, fat, total solids, and solids not-fat in the milk of lactating cows reared on Megathyrsus maximus cv. Tanzania pastures subjected to a variable (TZ95) or a fixed 30-day (TZ30) defoliation interval

\begin{tabular}{lcccc}
\hline \multirow{2}{*}{\multicolumn{1}{c}{ Component }} & \multicolumn{2}{c}{ Management strategy } & \multirow{2}{*}{ SEM $^{(1)}$} & \multirow{2}{*}{ P-value } \\
\cline { 2 - 3 } & TZ95 & TZ30 & & \\
\hline Milk yield (kg milk/cow.day) & 13.14 & 11.47 & 0.43 & $<0.0001$ \\
FCMY (kg milk/cow.day) & 13.69 & 12.16 & 0.54 & $<0.0001$ \\
Milk yield (kg milk/ha/grazing cycle) & 2723.33 & 1893.87 & 99.30 & 0.0002 \\
FCMY (kg milk/ha/grazing cycle) & 2840.37 & 1844.40 & 125.17 & 0.0002 \\
& & Chemical composition & \\
Protein $(\mathrm{g} / \mathrm{kg} \mathrm{DM})$ & 30.21 & 31.86 & 0.49 & $<0.0001$ \\
Lactose $(\mathrm{g} / \mathrm{kg} \mathrm{DM})$ & 48.82 & 44.37 & 0.21 & $<0.0001$ \\
Fat $(\mathrm{g} / \mathrm{kg} \mathrm{DM})$ & 37.73 & 38.83 & 1.15 & 0.52 \\
Total solids $(\mathrm{g} / \mathrm{kg} \mathrm{DM})$ & 121.02 & 125.80 & 1.37 & 0.0007 \\
Solids not-fat $(\mathrm{g} / \mathrm{kg} \mathrm{DM})$ & 82.63 & 86.95 & 0.61 & $<0.0001$ \\
\hline
\end{tabular}

${ }^{(1)}$ Standard error of the mean. ${ }^{(2)}$ Probability.

In addition to contributing to increasing the number of leaf blades and the CP content, the use of a variable defoliation interval resulted in higher $(\mathrm{P}=0.01)$ IVDMD of the herbage. The greater in vitro digestibility found in the management with a variable defoliation interval would allow for a better utilization of the herbage DM by the animals, since low digestibility implies a shorter retention time of the herbage in the rumen, causing physical limitations. Around 40 to $60 \%$ of the variations in intake between forage plants can be attributed to differences in digestibility (Sun Wang, Zhong, \& Zhou, 2014).

The digestion of the cell wall of forage plants is a process of paramount importance, as it is closely related to its chemical composition. Of the cell wall components, lignin is considered to have the greatest negative effect on ruminal digestion because it affects the utilization of the morphogenetic structures and of the plant as a whole (Moreira, Leonel, Vieira, \& Pereira, 2013). The lignin contents found in the present study $(\mathrm{TZ95}=$ 33.34 and $\mathrm{TZ30}=35.88 \mathrm{~g} / \mathrm{kg} \mathrm{DM}$, Table 1) are lower than the $47 \mathrm{~g} / \mathrm{kg}$ DM reported by Fukumoto et al. (2010), who worked with a tropical grass (Tanzania grass) managed under a rotational grazing system.

Total DM intake $(\mathrm{P}=0.03)$ and herbage intake $(\mathrm{P}=0.01)$ (Table 2) were higher in the pastures managed with a variable defoliation interval. This was likely due to the higher CP content and IVDMD of the pastures subjected to grazing according to the light interception. Together, these characteristics likely contributed to greater efficiency in utilization of the herbage. According to Maeda et al. (2012), 
a higher feed intake may be a consequence of the stimulatory effect of protein on the efficiency of microbial protein synthesis and digestibility of DM, which consequently increased the dilution rate, leading to a higher energy intake.

When expressed relative to the animals' live weight, the mean total DM intake and herbage intake values were 3.18 and $2.87 \%$, respectively. As stated by Santana et al. (2013), good pasture is consumed at $3 \%$ of an animal's weight, which shows that feed was adequately available to the animals. The selection of the diet is the most important factor in the process that influences the nutritional condition of an animal. Therefore, variations in the grazing process as a consequence of changes in the canopy structure may have a marked influence on herbage intake. The structural characteristics of the pasture thus become important factors controlling herbage intake by the animals (Euclides et al., 2009). In the present study, the pasture managed with a variable defoliation interval showed a higher proportion of leaf blades, with a tendency $(\mathrm{P}=0.06)$ of decreased proportions of stem, influencing herbage intake (Table 2).

Milk yield was higher $(\mathrm{P}<0.0001)$ in the pastures managed with the variable defoliation interval, which can probably be explained by the higher herbage intake, higher $\mathrm{CP}$ digestibility, and higher IVDMD (Table 3). The higher feed efficiency (Table 2) observed when the flexible management strategy was adopted reinforces the benefit of this strategy to guide the producer in choosing the defoliation interval. The availability of a feedstuff of better nutritional value led to the better nutrient utilization efficiency. As a consequence of the higher milk yield and decreased defoliation interval, the number of paddocks used throughout each grazing cycle decreased, resulting in a higher milk yield per area (Table 3).

The protein $(\mathrm{P}<0.0001)$, lactose $(\mathrm{P}<0.0001)$, total solids $(\mathrm{P}=0.0007)$, and solids not-fat $(\mathrm{P}<0.0001)$ contents in the milk differed across the management strategies (Table 3). The larger milk production observed in the pastures under the flexible management strategy likely contributed to lower concentrations of protein, total solids, and solids not-fat contents in the milk, in a dilution effect.

By contrast, the higher lactose content observed in the pastures managed with a variable defoliation interval were consistent with the higher individual milk yield of the animals managed in those pastures, since this component maintains the osmotic balance between milk and blood through the removal of water from the extra- and intracellular fluids. In this way, higher lactose secretion means more water is required to form milk. Cai, Wang and Lui (2018) reported that lactose is the main osmotic component of milk, as it is directly linked to the secretion of water and to the volume of milk produced. The lower roughage-to-concentrate found in the diet consumed by those animals might have allowed for an increase in the production of propionic acid, the main precursor of lactose, and thus increased the milk lactose content (Lima et al., 2011).

The milk fat content did not differ $(\mathrm{P}=0.52)$ with the tested management strategies (Table 3 ). This result is in line with the lack of differences in NDF content in the pastures regardless of the management strategy. According to Branco et al. (2010), the percentage of fat in milk rises linearly in response to the NDF concentration in the diet. The observed average fat content agrees with the value obtained by Voltolini, Santos and Martinez (2010) in a study with elephant grass managed under different grazing frequencies.

\section{Conclusions}

Despite providing a lower herbage allowance, the adoption of a variable defoliation interval defined by the interception of $95 \%$ of the photosynthetically active radiation leads to increased proportions of leaf blade in the forage canopy, crude protein content, and in vitro dry matter digestibility of the 
herbage. Animal performance is thus improved, with increased milk yield per cow and per area.

\section{Acknowledgments}

The authors thank the Foundation for Research Support of the Minas Gerais State (FAPEMIG) and EMBRAPA Dairy Cattle for the financial support.

\section{References}

Akaike, H. (1974). A new look at the statistical model identification. IEEE Transaction on Automatic Control, 19(6), 716-723. doi: 10.1109/ TAC.1974.1100705

Andrade-Montemayor, H., Gasca, T. G., \& Kawas, J. (2009). Ruminal fermentation modification of protein and carbohydrate by means of roasted and estimation of microbial protein synthesis. Revista Brasileira de Zootecnia, 38(Supl. Esp.), 277-291. doi: 10.1590/S1516-35982009001300028

Association of Official Analytical Chemistry. (1990). Official methods of analysis. 15nd ed. Arlington: AOAC International.

Branco, R. H., Rodrigues, M. T., Silva, M. M. C., Rodrigues, C. A. F., Queiroz, A. C., \& Araújo, F. A. (2010). Efeito dos níveis de fibra da forragem sobre o consumo, a produção e a eficiência de utilização de nutrientes em cabras lactantes. Revista Brasileira de Zootecnia, 39(11), 2477-2485. doi: 10.1590/S151635982010001100022

Cai, J., Wang, D., \& Lui, J. (2018). Regulation of fluid flow through the mammary gland of dairy cows and its effect on milk production: a systematic review. Journal of the Science Food and Agriculture, 98(4), 1261-1270. doi: 10.1002/jsfa.8605

Euclides, V. P. B., Macedo, M. C. M., Valle, C. B., Difante, G. S., Barbosa, R. A., \& Cacere, E. R. (2009). Valor nutritivo da forragem e produção animal em pastagens de Brachiaria brizantha. Pesquisa Agropecuária Brasileira, 44(1), 98-106. doi: 10.1590/S0100-204X2009000100014

Euclides, V. P. B., Montagner, D. B., Difante, G. S., Barbosa, R. A., \& Fernandes, W. S. (2014). Sward structure and livestock performance in guinea grass $\mathrm{cv}$. Tanzania pastures managed by rotational stocking strategies. Scientia Agricola, 71(6), 451-457. doi: 10.1590/0103-9016-2013-0272
Fukumoto, N. M., Damasceno, J. C., Deresz, F., Martins, C. E., Coser, A. C., \& Santos, G. T. (2010). Milk yield and composition, feed intake and stocking rate of crossbread cows in tropical grasses managed in a rotational grazing system. Revista Brasileira de Zootecnia, 39(7), 1548-1557. doi: 10.1590/S151635982010000700022

Gaines, W. L. (1928). The energy basis of measuring milk yield in dairy cows. Urbana: Illinois Agricultural Experiment Station Bulletin 308.

Gomes, R. S., Oliveira, T. S., Pereira, J. C., Vieira, R. A. M., Silva, C. J., Leonel, F. P., Azevedo, F. H. V. (2016). Kinetics of digestion of low-quality forage grazed by beef cattle fed supplements containing increasing levels of rumen undegradable protein. Revista Brasileira de Zootecnia, 45(9), 563-571, 2016. doi: 10.1590/s1806-92902016000900009

Kimura, F. T., \& Miller, V. L. (1957). Chromic oxide measurement. Improved determination of chromic oxide in cow feed and feces. Journal of Agricultural and Food Chemistry, 5(3), 216-216. doi: 10.1021/ jf60073a008

Lima, L. S., Oliveira, R. L., Bagaldo, A. R., Garcez, A. F., Neto, Ribeiro, C. V. M., \& Lanna, D. P. D. (2011). Composition and fatty acid profile of milk from cows on pasture subjected to licuri oil supplement. Revista Brasileira de Zootecnia, 40(12), 2858-2865. doi: 10.1590/S1516-35982011001200033

Macedo, V. H. M., Cunha, A. M. Q., Cândido, E. P., Domingues, F. N., Melo, D. M., \& Rêgo, A. C. (2017). Estrutura e produtividade de capim-tanzânia submetido a diferentes frequências de desfolhação. Ciência Animal Brasileira, 18(e-38984), 1-10. doi: 10.1590/1809-6891v18e-38984

Maeda, E. M., Zeola, L. M., Jobim, C. C., Cecato, U., Rigolon, L. P., Kazama, R., Carvalho, A. F. G. (2012). Intake, digestibility, rumen characteristics and microbial protein synthesis efficiency in bovine and bubaline fed sugar cane silage with additives. Revista Brasileira de Zootecnia, 41(3), 707-716. doi: 10.1590/S1516-35982012000300034

Moreira, L. M., Leonel, F. P., Veira, R. A. M., \& Pereira, J. C. (2013). A new approach about the digestion of fibers by ruminants. Revista Brasileira de Saúde e Produção Animal, 14(2), 382-395. doi: 10.1590/ S1519-99402013000200008

Pinheiro, A. A., Cecato, U., Lins, T. O. J. D. A., Beloni, T., Krutzmann, A., Iwamoto, B. S., \& Mari, G. C. (2015). Acúmulo e composição morfológica do pasto de capim tanzânia adubado com nitrogênio 
ou consorciado com estilosantes campo grande. Bioscience Journal, 31(3), 850-858. doi: 10.14393/ BJ-v31n3a2015-22013

Reis, R. A., Ruggieri, A. C., Oliveira, A. A., Azenha, M. V., \& Casagrande, D. R. (2012). Suplementação como estratégia de produção de carne de qualidade em pastagens tropicais. Revista Brasileira de Saúde e Produção Animal, 13(3), 642-655. doi: 10.1590/ S1519-99402012000300005

Santana, M. C. A., Euclides, V. B. P., Mancio, A. B., Medeiros, S. R., Costa, J. A. R., \& Oliveira, R. L. (2013). Intake and performance of yearling steers grazing guinea grass (Panicum maximum cv. Tanzânia) pasture supplemented with different energy sources. Asian-Australisian Journal of Animal Sciences, 26(3), 349-357. doi: 10.5713/ ajas.2012.12226

Shallo, L., Creighton, P., \& O’Donovan, M. (2011). The economics of reseeding on a dairy farm. Irish Journal of Agricultural and Food Research, 50(1), 113-122. doi: 10.2307/41348159

Silva, D. J., \& Queiroz, C. (2006). Análise de alimentos: métodos químicos e biológicos. Viçosa, MG: UFV.

Silva, S. C., Bueno, A. A. O., Carnevalli, R. A., Uebele, M. C., Bueno, F. O., Hodgson, J...., \& Morais, J. P. G. (2009). Sward structural characteristics and herbage accumulation of Panicum maximum cv. Mombaça subjected to rotational stocking managements. Scientia Agricola, 66(1), 8-19. doi: 10.1590/S010390162009000100002
Sousa, B. M. L., Nascimento, D., Jr., Rodrigues, C. S., Monteiro, H. C. F., Silva, S. C., Fonseca, D. M., \& Sbrissia, A. F. (2011). Morphogenetic and structural characteristics of xaraes palisadegrass submitted to cutting Heights. Revista Brasileira de Zootecnia, 40(1), 53-59. doi: 10.1590/S151635982011000100008

Sun, Z., Wang, Z., Zhong, Q., \& Zhou, D. (2014). Seasonal variations in voluntary intake and apparent digestibility of forages in goats grazing on introduced Leymus chinensis pasture. Asian-Australasian Journal of Animal Science, 27(6), 818-824. doi: 10.5713/ajas.2013.13626

Valente, B. S. M., Cândido, M. J. D., Cutim, J. A. A., Jr., Pereira, E. S., Bomfim, M. A. D., \& Feitosa, J. V. (2010). Composição químico-bromatológica, digestibilidade e degradação in situ da dieta de ovinos em capim Tanzânia sob três frequências de desfolhação. Revista Brasileira de Zootecnia, 39(1), 113-120. doi: 10.1590/S1516-35982010000100015

Van Soest, P. J. (1994). Nutritional ecology of the ruminant (2nd ed.), Ithaca: Cornell Univ. Press.

Voltolini, T. V., Santos, F. A. P., \& Martinez, J. C. (2010). Produção e composição do leite de vacas mantidas em pastagens de capim-elefante submetidas a duas frequências de pastejo. Revista Brasileira de Zootecnia, 39(1), 121-127. doi: 10.1590/S151635982010000100016

Zanine, A. M., Nascimento, D., Jr., Santos, M. E. R., Pena, K. S., Silva, S. C. I., \& Sbrissia, A. F. (2011). Características estruturais e acúmulo de forragem em capim-tanzânia sob pastejo rotativo. Revista Brasileira de Zootecnia, 40(11), 2364-2373. doi: $10.1590 / \mathrm{S} 1516-35982011001100012$ 